Primljen/Received: 12.6.2015. Ispravljen/Corrected: 17.2.2017.

Prihvaćen/Accepted: 18.5.2017.

Dostupno online/Available online: 10.10.2017.

\section{Influence of fly ash and decreasing water-powder ratio on performance of recycled aggregate concrete}

Authors:

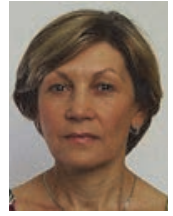

${ }^{1}$ Prof. Mirjana Malešev, PhD. CE miram@uns.ac.rs

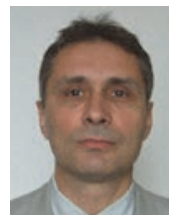

${ }^{1}$ Prof Vlastimir Radonjanin, PhD. CE radonv@uns.ac.rs

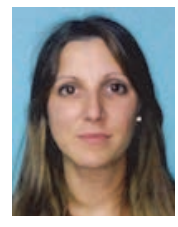

${ }^{1}$ Suzana Draganić, MSc. CE suzanav@uns.ac.rs

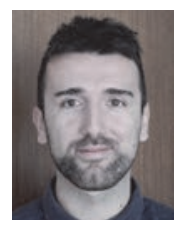

${ }^{1}$ Slobodan Šupić, MSc. CE ssupic@uns.ac.rs

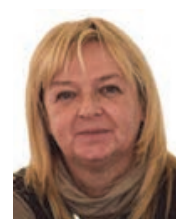

${ }^{1}$ Assist.Prof. Mirjana Laban, PhD. CE mlaban@uns.ac.rs

${ }^{1}$ University of Novi Sad

Faculty of Technical Sciences

Department of Civil Engineering and Geodesy
Preliminary report

Mirjana Malešev, Vlastimir Radonjanin, Suzana Draganić, Slobodan Šupić, Mirjana Laban

Influence of fly ash and decreasing water-powder ratio on performance of recycled aggregate concrete

Investigation results of the combined effect of partial cement replacement with fly ash, and the use of recycled concrete aggregate to improve the sustainability of concrete, are presented in this paper. The compressive strength, capillary water absorption, water permeability, and chloride ion penetration, are analysed by testing nine concrete mixtures, in which the fly ash content and water to powder ratio were varied. The results show that compressive strength slightly decreases as the fly ash content increases, but that this can be compensated by reducing the water to powder ratio.

Key words:
recycled aggregate, fly ash, sustainability, compressive strength, durability

Prethodno priopćenje

Mirjana Malešev, Vlastimir Radonjanin, Suzana Draganić, Slobodan Šupić, Mirjana Laban

Utjecaj letećeg pepela i smanjenja vodovezivnog omjera na svojstva betona s recikliranim agregatom

U radu su prikazani rezultati ispitivanja zajedničkog učinka djelomične zamjene cementa s letećim pepelom i upotrebe recikliranog agregata s ciljem poboljšanja održivosti betona. Ispitivano je devet betonskih mješavina, u kojima su varirani količina letećeg pepela i vodovezivni omjer, analizirani su: tlačna čvrstoća, kapilarno upijanje, vodopropusnost i otpornost na prodor klorida. Dobiveno je da se povećanjem količine letećeg pepela neznatno smanjuje tlačna čvrstoća, ali da se smanjenjem vodovezivnog omjera to može nadomjestiti.

Ključne riječi:

reciklirani agregat, leteći pepeo, održivost, tlačna čvrstoća, trajnost

Vorherige Mitteilung

Mirjana Malešev, Vlastimir Radonjanin, Suzana Draganić, Slobodan Šupić, Mirjana Laban

Einfluss von Flugasche und der Reduktion des Wasserbindemittelwerts auf die Eigenschaften von Beton mit wiederverwertetem Aggregat

In der Arbeit werden die Prüfergebnisse der gemeinsamen Auswirkung eines Teilersatzes von Zement durch Flugasche und des Einsatzes von wiederverwertetem Aggregat zur VerbesserungderDauerhaftigkeitvon Betondargestellt. EswurdenneunBetonmischungen untersucht, bei welchen die Menge von Flugasche und das Verhältnis Wasser-Bindemittel variiert wurden, dabei wurden folgende Werte analysiert: Druckfestigkeit, kapillare Absorption und Beständigkeit auf die Durchdringung von Chloriden. Es hat sich gezeigt, dass eine Erhöhung des Anteils von Flugasche die Druckfestigkeit unbedeutend reduziert, was aber durch die Reduktion des Wasserbindemittelwerts ersetzt werden kann.

Schlüsselwörter:

wiederverwertetes Aggregat, Flugasche, Nachhaltigkeit, Druckfestigkeit, Dauerhaftigkeit 


\section{Introduction}

The expansion of the world's population has led to an exponential increase in the consumption of natural resources and energy, consequently leading to the increasing amounts of waste. Therefore, the construction and demolition waste recycling is a vital step towards environmental sustainability in construction industry [1]. Recycled coarse aggregate, and especially the recycled concrete aggregate (RCA), has been used for more than seventy years in civil engineering. Research results on the properties of concrete with coarse RCA have been extensively reviewed and discussed [2-5]. The general conclusion is that the strength and durability properties of concrete containing RCA are worse than the comparable properties of concrete containing natural aggregate. There is a consensus in literature that durability properties decrease with an increase in the RCA replacement level, [1]. However, these properties are still sufficient for some applications in the civil engineering practice.

Besides natural aggregate replacement, waste and supplementary cementing materials such as fly ash, blast furnace slag, silica fume, rice husk ash and metakaolin can also be used as partial replacement for Portland cement. These materials can improve concrete durability, reduce the risk of thermal cracking in mass concrete, and are less energy and $\mathrm{CO}_{2}$ intensive than cement [6-9]. Generally, the use of mineral additions was found to have a positive effect on the resistance to chloride ion penetration. This improvement occurred at a fairly similar rate in RAC with higher replacement levels, and in the corresponding NAC [1].

The advantages of using fly ash in recycled aggregate concrete have been more intensively investigated over the last two decades. The authors have concluded that the most important benefit is the reduced permeability to water and aggressive chemicals [7,10-16]. For example, Kou at all [16] investigated 24 different concrete mixtures, with $0 \%$, $20 \%, 50 \%$ and $100 \%$ natural aggregate replacement by RCA, with $0 \%, 25 \%$ and $35 \%$ cement replacement by fly ash, and with two water-to-binder ratio values $(0,55$ and 0,45$)$. They concluded that the resistance to chloride ion penetration decreases as the RCA content increases. However, the resistance improves by incorporating fly ash and decreasing the water to binder ratio.

The objective of this research was to improve the strength and durability of concrete containing both waste materials: $100 \%$ recycled concrete aggregate and high volume of fly ash. This goal was achieved by reducing the water to powder ratio.

\section{Experimental research}

Based on previous test results for recycled aggregate concrete (RAC) $[17,18]$, the concrete in which $100 \%$ of natural coarse aggregate was replaced by RCA and containing high volume of fly ash (FA) was selected for further research. The influence of the FA quantity and water to powder ratio on the concrete compressive strength, capillary water absorption, chloride ion penetration and depth of water penetration under pressure were investigated in this phase of the study. All properties were tested at the age of 28 days. Nine different concretes were tested in order to determine the influence of high amount of fly ash and low water-powder (w/p) ratio on the selected properties of RAC. They were divided into three groups. In the first group, no fly ash was added. In the second group, $30 \%$ of cement was replaced with $\mathrm{FA}$, while $50 \%$ of cement was substituted with $\mathrm{FA}$ in the third group. The following three water-to-powder ratios were used in each group: 0.54, 0.40 and 0.30 . RCA was used as coarse aggregate in all concretes. A total of 81 specimens were made for testing properties of hardened concrete.

\subsection{Materials}

Component materials used in this study are:

- Portland cement CEM I 42.5R (Lafarge - BFC Serbia),

- Fine aggregate (natural aggregate, the Drina River, 0/4 mm),

- Coarse aggregate (recycled concrete aggregate, unknown origin, 4/8 and 8/16 mm),

- Fly ash (Power Plant "Nikola Tesla B" Obrenovac - Serbia),

- HRWRA 1 ("Sika ViscoCrete 3070", "Sika"- Switzerland, $\gamma_{s}=$ $\left.1090 \mathrm{~kg} / \mathrm{m}^{3}\right)$,

- HRWRA 2 ("Sika ViscoCrete 5500MP", "Sika"- Switzerland, $\gamma_{\text {s }}$ $\left.=1100 \mathrm{~kg} / \mathrm{m}^{3}\right)$,

- Tap water.
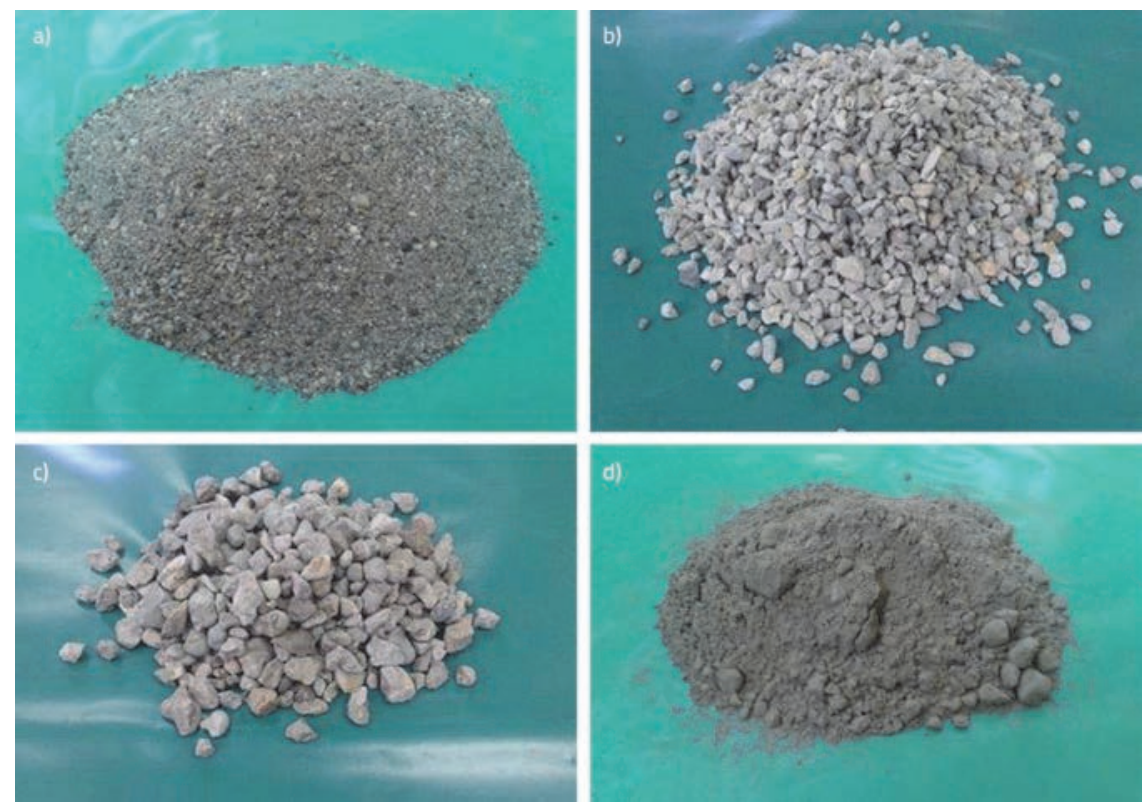

Figure 1. Aggregate and fly ash: Fine river aggregate (0-4 mm); b) RCA (4-8 $\mathrm{mm})$; c) RCA (8-16 $\mathrm{mm})$; d) Fly ash 
Table 1. Chemical composition and specific gravity of cement and fly ash

\begin{tabular}{|l|c|c|c|c|c|c|c|c|c|c|c|c|}
\hline Material & $\mathrm{SiO}_{2}[\%]$ & $\mathrm{Al}_{2} \mathrm{O}_{3}[\%]$ & $\mathrm{Fe}_{2} \mathbf{O}_{3}[\%]$ & $\mathbf{C a O}[\%]$ & $\mathrm{Na}_{2} \mathbf{O}[\%]$ & $\mathbf{K}_{2} \mathbf{O}[\%]$ & $\mathrm{TiO}_{2}[\%]$ & $\mathbf{M g O}[\%]$ & $\mathbf{P}_{2} \mathbf{O}_{5}[\%]$ & $\mathbf{S O}_{3}[\%]$ & LOI [\%] & Specific gravity [g/cm 3$]$ \\
\hline Cement & 21.25 & 5.55 & 25.30 & 61.60 & 0.25 & 0.72 & - & 2.37 & - & 3.75 & 1.77 & 3.1 \\
\hline Fly ash & 58.24 & 20.23 & 5.33 & 7.62 & 0.52 & 1.51 & 0.45 & 2.01 & 0.00 & 2.21 & 1.64 & 2.1 \\
\hline
\end{tabular}

The aggregate and FA used in the study are shown in Figure 1. The chemical composition and specific gravity of the cement and fly ash have been tested according to standards SRPS EN 196-2 and SRPS EN 196-6 [19]. The results obtained are given in Table 1.

Based on the fineness testing results, FA has been classified according to EN 450-1 as type $\mathrm{N}$. The scanning electron microscopy (SEM) was used to determine general physical characteristics of cement and fly ash particles. SEM images showing typical morphology of fly ash and cement are shown in Figure 2. The majority of fly ash particles consist of solid spheres, while cement particles exhibit an irregular polygonal shape. Fly ash particles could fill the internal structure of the cement, because they are much finer than Portland cement particles, as shown in Figure 2.

The content of the old hardened cement paste attached to the original natural aggregate in the RCA was determined by dissolution in the $16 \%$ hydrochloric acid. The results showed that the recycled aggregate comprises $38 \%$ of bound mortar. All presented properties of RAC were tested according to appropriate European standards, except for resistance to crushing by compression in cylinder, which was tested in compliance with the corresponding national standard. Particle size distribution of aggregates was determined by sieve analysis (Table 2). Other tested properties of aggregate are given in Table 3.

Table 3. Properties of aggregates

\begin{tabular}{|c|c|c|c|c|c|}
\hline $\begin{array}{c}\text { Type of } \\
\text { aggregate }\end{array}$ & $\begin{array}{c}\text { Apparent } \\
\text { bulk } \\
\text { density } \\
{\left[\mathrm{kg} / \mathrm{m}^{3}\right]}\end{array}$ & $\begin{array}{c}\text { Chloride } \\
\text { content } \\
{[\%]}\end{array}$ & $\begin{array}{c}\text { Fines } \\
\text { content } \\
{[\%]}\end{array}$ & $\begin{array}{c}\text { Water } \\
\text { absorption } \\
\text { after } \\
\mathbf{6 0} \text { min } \\
{[\text { mas. } \%]}\end{array}$ & $\begin{array}{c}\text { Crushability } \\
\text { by } \\
\text { compression } \\
{[\%]}\end{array}$ \\
\hline $\begin{array}{c}\text { NA } \\
\text { O/4 mm }\end{array}$ & 2650 & - & 0.64 & $<1$ & $\begin{array}{c}\text { not } \\
\text { demanded }\end{array}$ \\
\hline $\begin{array}{c}\text { RCA } \\
4 / 8 \mathrm{~mm}\end{array}$ & 2350 & 0.03 & 0.03 & 5.1 & 17 \\
\hline $\begin{array}{c}\text { RCA } \\
8 / 16 \mathrm{~mm}\end{array}$ & 2350 & 0.03 & 0.04 & 3.5 & 20 \\
\hline
\end{tabular}
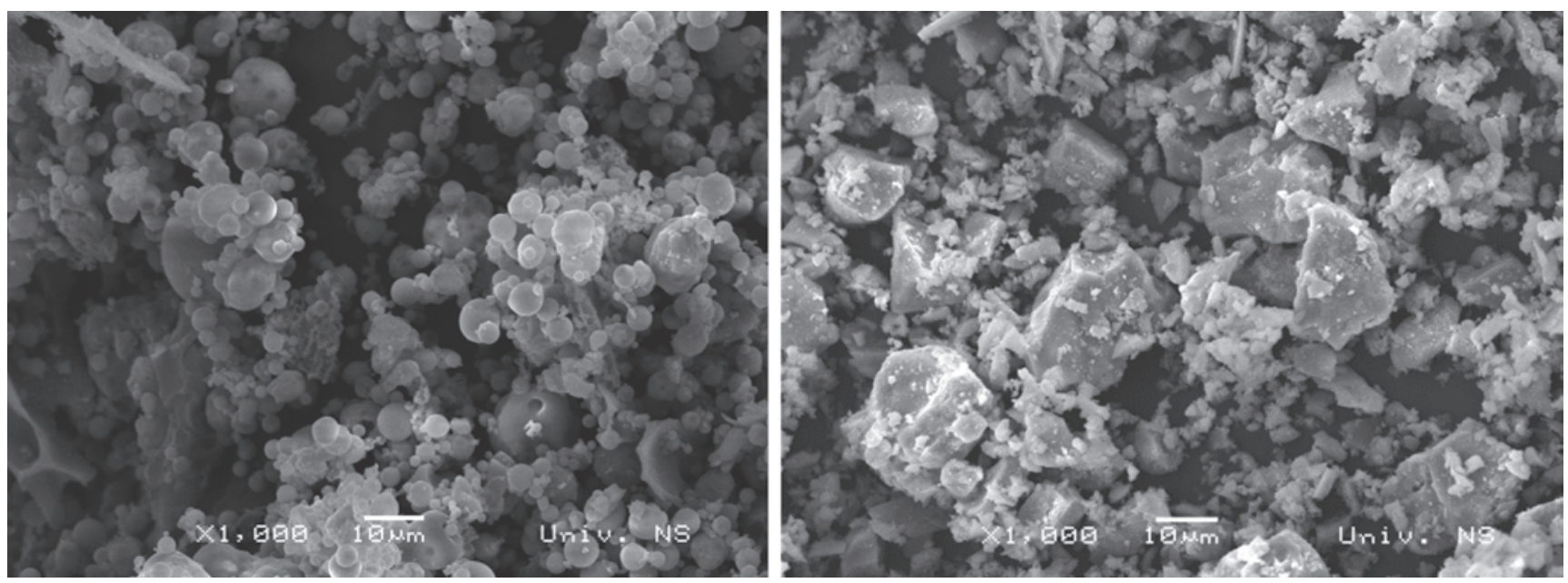

Figure 2. SEM images: fly ash and CEM I magnified 1000x

Table 2. Aggregate particle size distribution [\%]

\begin{tabular}{|c|c|c|c|c|c|c|c|c|c|}
\hline Sieve size $[\mathrm{mm}]$ & $\mathbf{0 , 1 2 5}$ & $\mathbf{0 , 2 5}$ & $\mathbf{0 , 5}$ & $\mathbf{1}$ & $\mathbf{2}$ & $\mathbf{4}$ & $\mathbf{8}$ & $\mathbf{1 6}$ & $\mathbf{3 1 , 5}$ \\
\hline NA 0/4 mm & 1 & 15 & 56 & 74 & 84 & 95 & 100 & 100 & 100 \\
\hline RCA 4/8 mm & 1 & 1 & 1 & 2 & 2 & 4 & 90 & 100 & 100 \\
\hline RCA 8/16 mm & 0 & 0 & 0 & 0 & 0 & 0 & 3 & 99 & 100 \\
\hline
\end{tabular}


The apparent bulk density meets the criterion for RCA (>2100kg/ $\mathrm{m}^{3}$ ). Fines content of RAC is negligible. Criteria for crushability by RAC compression were also fulfilled $(<30 \%)$.

\subsection{Mix design}

Concrete mix proportions were determined based on the following assumptions:

- Absolute volume of powder and water were around $0.3 \mathrm{~m}^{3}$, the absolute volume of aggregate was approximately $0.7 \mathrm{~m}^{3}$ and they were kept constant in all mixtures.

- Maximum grain size was $16 \mathrm{~mm}$.

- $50 \%$ of the total aggregate was fine river aggregate (grain size $0 / 4 \mathrm{~mm}$ ) and $50 \%$ was coarse recycled aggregate (grain size $4 / 8 \mathrm{~mm}$ and $8 / 16 \mathrm{~mm}$ ). The grain-size composition of the aggregate mixture matches the Fuller's continuous curve.

- Additional amount of water was determined by water absorption of recycled aggregate.

- The amount of super-plasticizer was based on the need to achieve the required consistency.

- Air content was approximately 1-2\%.

The quantities of component materials for $1 \mathrm{~m}^{3}$ of concrete mix were calculated based on these conditions. The designed quantities of component materials are shown in $\mathrm{kg} / \mathrm{m}^{3}$ in Table 4.

\subsection{Methods}

The fresh concrete consistency was determined by slump test (EN 12350-2) and air content was measured by pressure method according to EN 12350-7. All specimens were compacted on the vibrating table. The compressive strength of concrete was tested in accordance with SRPS ISO 4012 [20] on $15 \mathrm{~cm}$ cubes as shown in Figure 3. Three specimens were tested for each concrete type.

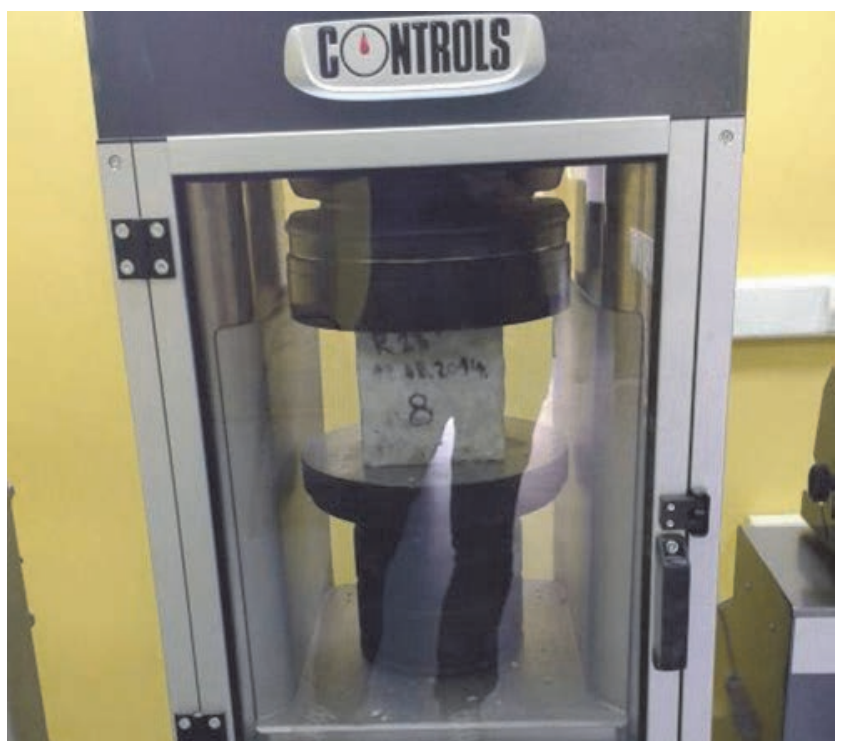

Figure 3. Compressive strength testing

The capillary water absorption of investigated concretes was measured according to SRPS U.M8.300 [21]. Three cylindrical specimens $95 \mathrm{~mm}$ in diameter and $50 \mathrm{~mm}$ in thickness were used for this test. Preconditioning of specimens was conducted according to BS 1881-122 [22]. Before measuring the mass of conditioned specimens, their side surfaces were sealed with a waterproofing membrane. Then, the bottom side of the specimens was immersed in tap water up to a maximum depth of 5 millimetres. The uptake of water by capillary absorption was measured via the weight of the specimens, $\mathrm{m}(\mathrm{t})$, at the time intervals of 1, 2,15, 30 minutes, $1 \mathrm{~h}, 4 \mathrm{~h}$ and 25 hours from the contact with water.

Two chloride permeability tests were performed in order to determine resistance to chloride penetration. The first test was the Rapid Chloride Penetration Test (RCPT), described in

Table 4. Mix proportions of RAC in $\mathrm{kg} / \mathrm{m}^{3}$

\begin{tabular}{|c|c|c|c|c|c|c|c|c|}
\hline \multirow{2}{*}{$\begin{array}{l}\text { Concrete } \\
\text { type }\end{array}$} & \multirow{2}{*}{$\begin{array}{c}\text { Cement } \\
\mathrm{m}_{\mathrm{c}}\end{array}$} & \multirow{2}{*}{$\begin{array}{c}\begin{array}{c}\text { Mineral } \\
\text { admixture }\end{array} \\
\text { FA } \\
\end{array}$} & \multirow{2}{*}{$\begin{array}{l}\text { Water } \mathrm{m}_{\mathrm{w}, \text { tot }} \\
\mathrm{m}_{\mathrm{w}}+\mathrm{m}_{\mathrm{w}, \text { add }}{ }^{\mathrm{a}}\end{array}$} & \multirow{2}{*}{$\begin{array}{c}\text { Water / } \\
\text { powder ratio }\end{array}$} & \multicolumn{3}{|c|}{ Aggregate } & \multirow{2}{*}{$\begin{array}{c}\text { Chemical admixture } \\
\text { HRWRA }\end{array}$} \\
\hline & & & & & NA $0 / 4$ & RCA 4/8 & RCA 8/16 & \\
\hline E1 & 350 & - & $190+35.6$ & 0.543 & 849 & 373 & 475 & - \\
\hline E2 & 412 & - & $165+35.6$ & 0.404 & 849 & 373 & 475 & 2,5 \\
\hline E3 & 473 & - & $142+35.6$ & 0.309 & 849 & 373 & 475 & $5.7^{b}$ \\
\hline R11 & 255 & 76,8 & $180.7+35.6$ & 0.543 & 849 & 373 & 475 & - \\
\hline R12 & 304 & 91 & $158+35.6$ & 0.401 & 849 & 373 & 475 & 0.79 \\
\hline R13 & 348 & 104 & $135.6+35.6$ & 0.304 & 849 & 373 & 475 & 2.71 \\
\hline R21 & 218 & 109 & $177.6+35.6$ & 0.543 & 849 & 373 & 475 & - \\
\hline R22 & 257 & 129 & $154.4+35.6$ & 0.403 & 849 & 373 & 475 & 1.54 \\
\hline R23 & 295 & 148 & $133+35.6$ & 0.303 & 849 & 373 & 475 & 1.77 \\
\hline
\end{tabular}


ASTM C1202-2012 [23], and the second test method was the Colorimetric method described in NT Build 492 [24].

The RCPT includes a conditioning and a testing phase. The RCPT test method consists of monitoring the amount of electrical current that passes through cylinders $(50 \mathrm{~mm}$ in thickness and $95 \mathrm{~mm}$ in diameter) during a period of 6 hours. A potential difference of $60 \mathrm{~V}(\mathrm{dc})$ was maintained across the ends of the specimen, one of which was immersed in a $3 \%$ sodium chloride solution, whereas the other was submerged in a $3 \mathrm{~N}$ sodium hydroxide solution. The total charge that passed through the specimen was measured in coulombs and it indicated the resistance of the specimen to chloride ion penetration. Twenty seven specimens in total were exposed to electric field inducing the migration of chloride ions (Figure 4).

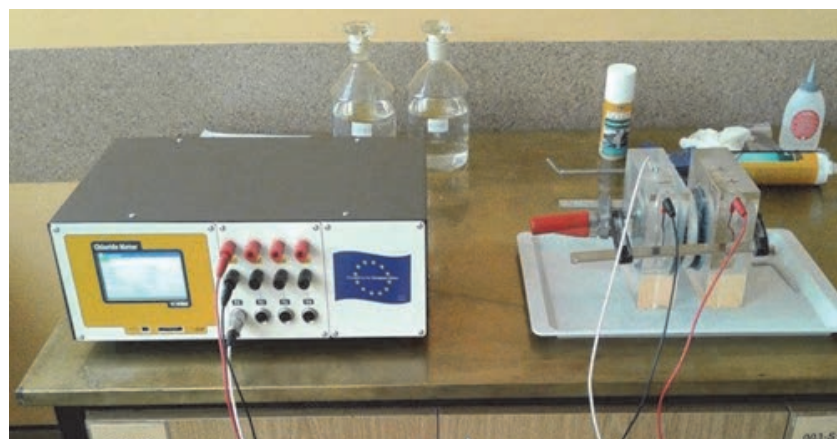

Figure 4. Measuring electrical conductivity of concrete

The NT BUILD 492 test method also encompasses a conditioning and a testing phase. Three cylindrical specimens measuring 95 $\mathrm{mm}$ in diameter and $50 \mathrm{~mm}$ in thickness were used in this test for each concrete type. During the testing phase an external electrical potential was applied axially across the specimen and it forced the chloride ions to migrate from outside into the specimen. After 24 hours, the specimen was axially split and a silver nitrate solution was sprayed onto one of the freshly split sections. The chloride penetration depth was measured from the visible white silver chloride precipitation (Figure 5), after which the non-steady-state migration coefficients were calculated using Equation (1).

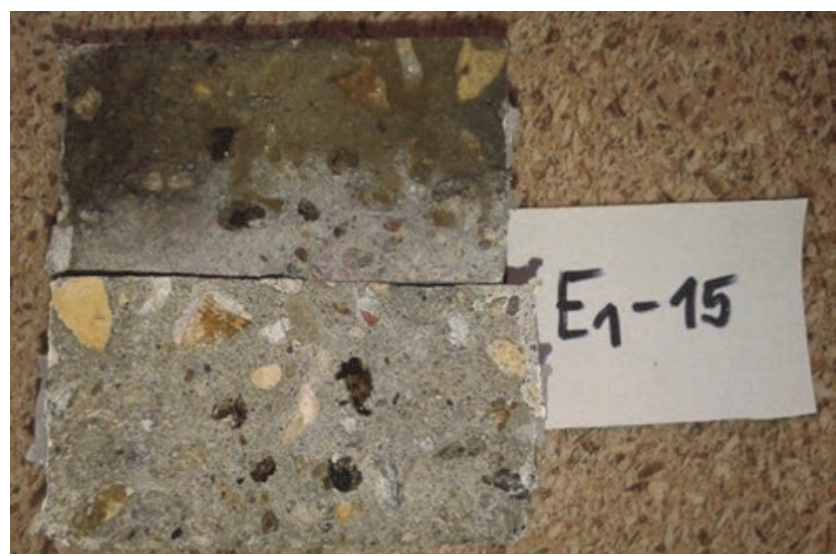

Figure 5. Colorimetric test method

$$
D_{\text {nssm }}=\frac{0.0239 \cdot(273+T) \cdot L}{(U-2) \cdot t} \cdot\left(x_{d}-0.0238 \cdot \sqrt{\frac{(273+T) \cdot L \cdot x_{d}}{U-2}}\right)
$$

where:

$D_{\text {nssm }}$ - non-steady-state migration coefficient, $\times 10^{-12}\left[\mathrm{~m}^{2} / \mathrm{s}\right]$

U - absolute value of applied voltage [V]

$\mathrm{T}$ - average value of the initial and final temperatures in the anolyte solution $\left[{ }^{\circ} \mathrm{C}\right]$

$\mathrm{L} \quad$ - thickness of the specimen [mm]

$x_{d} \quad$ - average value of penetration depths [mm]

$\mathrm{t} \quad$ - test duration [hours].

The method for determining the depth of water penetration under pressure into hardened concrete is described in SRPS EN 12390-8 [25]. The specimens used in the study were $150 \mathrm{~mm}$ cubes. The specimens were preconditioned for 7 days at $60 \pm$ $5 \%$ of relative humidity at $20 \pm 2{ }^{\circ} \mathrm{C}$. At the age of 28 days the water under pressure of $500 \mathrm{kPa}$ was applied onto the surface of hardened concrete during 72 hours (Figure 6). The specimen was then split and the depth of penetration of the water front was measured (Figure 7).

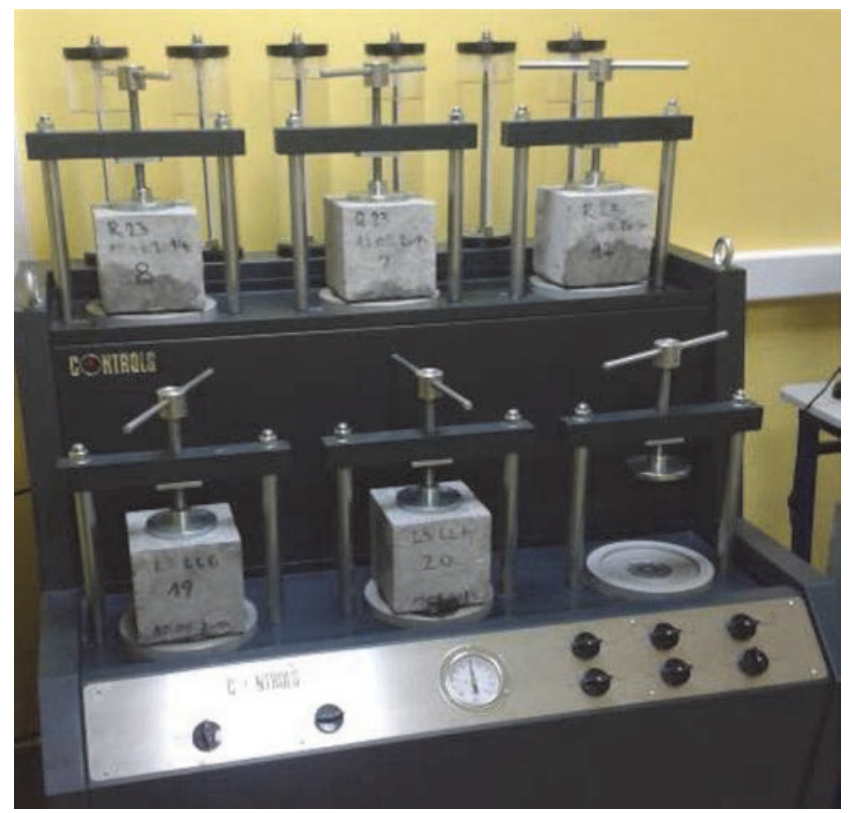

Figure 6. Water penetration test

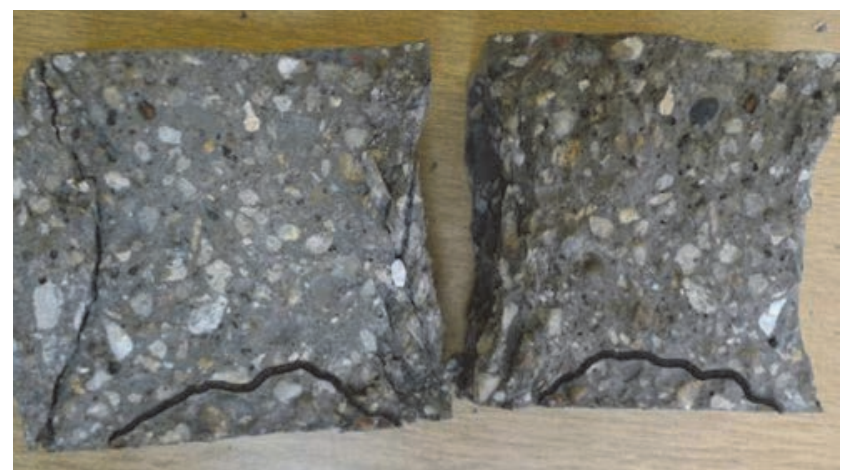

Figure 7. Visual determination of depth of water penetration 
Specimens used for testing compressive strength, capillary water absorption and chloride ion penetration were cured under water (at $20 \pm 2{ }^{\circ} \mathrm{C}$ ) up to the age of 28 days, while the specimens used for testing water penetration under pressure were cured for 21 days in the same conditions.

\section{Results and discussion}

\subsection{Consistency and air content of fresh concrete}

Results obtained by testing consistency and air content of fresh concrete are given in Table 5.Most of the tested concrete mixtures achieved the consistency of S2 according to SRPS EN 206-1 [26] and fulfilled the air content mix design requirements. By analysing the obtained results it was concluded that fly ash exerts no negative influence on the workability and air content.

\subsection{Concrete compressive strength}

Test results, w/p ratios, and effective water-binder $\left(w / b_{\text {eff }}\right)$ ratios, are shown in Table 6 and Figure 8. Effective water-binder ratios were calculated according to the k-value concept. The k-value concept, conforming to SRPS EN 206-1, permits fly ash to be taken into account by replacing the term "water/ cement ratio" with "water/(cement + $\mathrm{k} \times$ fly ash) ratio". The amount of fly ash that may be taken into account must meet the requirement: fly ash/cement $\leq 0.33$ by mass.

If a greater amount of fly ash is used, the excess shall not be taken into account for the calculation of the water/(cement $+\mathrm{k}$ $x$ fly ash) ratio. For concrete containing cement type CEM I, the permitted k-value is 0,4 according to EN 206-1 [26].

It can be seen from Figure 8 that there are no significant differences between the referent concrete and concrete with fly ash in the scope of the same $w / p$ ratio.

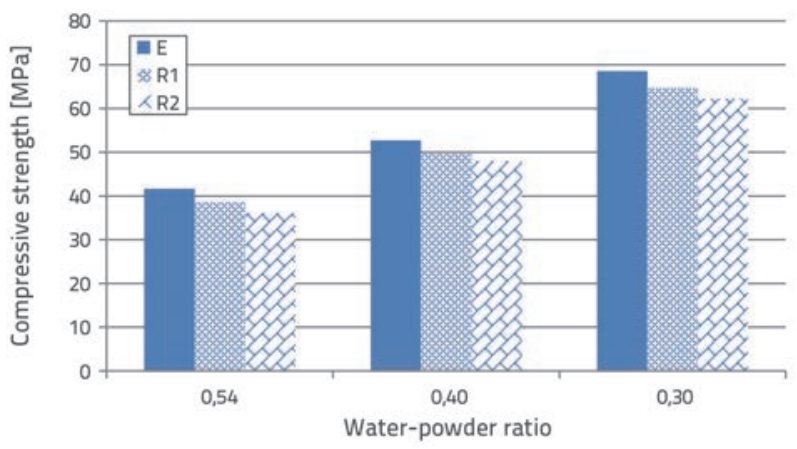

Figure 8. Correlation between concrete compressive strength and $w / p$ ratio for RAC

For concrete with $w / p$ ratio of 0.543 the difference between concretes $\mathrm{E} 1$ and $\mathrm{R} 11$ was approximately $3 \mathrm{MPa}(7 \%)$, while the difference between concretes E1 and R21 was nearly $5 \mathrm{MPa}$ (13 $\%)$. For concrete with $w / p$ ratio of 0.4 the difference between concretes E2 and R12 was approximately $3 \mathrm{MPa}(6 \%)$, while the difference between concretes E2 and R22 was nearly $5 \mathrm{MPa}$ $(9 \%)$. The same differences were observed for concretes with $\mathrm{w} / \mathrm{p}$ ratio of 0.3 . A significant increase in strength was observed due to reduced $w / p$ ratio. For $E$ series, differences between concretes $\mathrm{E} 1$ and E2, and $\mathrm{E} 1$ and E3, were $11 \mathrm{MPa}(27 \%)$ and $27 \mathrm{MPa}(65 \%)$, respectively. For R1 series, differences between concretes R11 and R12, and R11 and R13, were $11 \mathrm{MPa}(29 \%)$ and $26 \mathrm{MPa}(68 \%)$, respectively. For the series R2, differences between R21 and R22, and R21 and R23, were $12 \mathrm{MPa}$ (33\%) and $26 \mathrm{MPa}(72 \%)$, respectively.

The 28 day compressive strength ranged from $36.1 \mathrm{MPa}$ for the $50 \% \mathrm{FA}$ mix and $0.54 \mathrm{w} / \mathrm{p}$ ratio (concrete $\mathrm{R} 21$ ), to $68.53 \mathrm{MPa}$ for the $100 \% \mathrm{PC}$ mix and $0.3 \mathrm{w} / \mathrm{c}$ ratio (concrete E3).

The reduction in strength due to fly ash content can be compensated by an appropriate $w / p$ ratio. For example, concrete

Table 5. Consistency and air content of fresh concrete

\begin{tabular}{|c|c|c|c|c|c|c|c|c|c|}
\hline Concrete type & E1 & E2 & E3 & R11 & R12 & R13 & R21 & R22 & R23 \\
\hline $\mathbf{F A}[\%]$ & 0 & 0 & 0 & 30 & 30 & 30 & 50 & 50 & 50 \\
\hline$w / p$ & 0.543 & 0.404 & 0.309 & 0.543 & 0.401 & 0.304 & 0.543 & 0.403 & 0.303 \\
\hline SPC $[\%]$ & - & $0.6^{*}$ & $1.2^{*}$ & - & $0.2^{* *}$ & $0.6^{* *}$ & - & $0.4^{* *}$ & $0.4^{* *}$ \\
\hline $\mathbf{S}[\mathrm{mm}]$ & 70 & 70 & 40 & 75 & 60 & 80 & 70 & 90 & 80 \\
\hline$\Delta \mathrm{p}[\%]$ & 1.8 & 2.2 & 2.5 & 2.0 & 1.8 & 2.5 & 2.2 & 2.0 & 2.2 \\
\hline
\end{tabular}

Table 6. Compressive strength, $w / p$ ratio and effective $w / b$ ratio of RAC

\begin{tabular}{|c|c|c|c|c|c|c|c|c|c|}
\hline \multirow{2}{*}{ Concrete type } & \multicolumn{3}{|c|}{ Referent samples } & \multicolumn{3}{|c|}{ RAC (30\% FA) } & \multicolumn{3}{|c|}{ RAC (50\% FA) } \\
\hline & E1 & E2 & E3 & R11 & R12 & R13 & R21 & R22 & R23 \\
\hline$w / p$ & 0.543 & 0.4 & 0.3 & 0.543 & 0.4 & 0.3 & 0.543 & 0.4 & 0.3 \\
\hline$w / b_{\text {eff }}$ & 0.543 & 0.4 & 0.3 & 0.63 & 0.46 & 0.35 & 0.72 & 0.53 & 0.4 \\
\hline $\mathbf{f}_{c, 28}[\mathrm{MPa}]$ & 41.63 & 52.73 & 68.53 & 38.6 & 49.6 & 64.7 & 36.1 & 47.9 & 62.27 \\
\hline
\end{tabular}


E1 had the compressive strength of $41.63 \mathrm{MPa}$. An increase in strength of $8 \mathrm{MPa}(19 \%)$ can be achieved with partial replacement of cement with $30 \%$ fly ash and $w / p$ reduction from 0.543 to 0.4 . In the best case, the strength can be increased by $23 \mathrm{MPa}(55$ $\%$ ) with partial replacement of cement with $50 \%$ fly ash and w/p reduction from 0.543 to 0.3 . Consequently, a superplasticizer must be used in order to maintain the required workability.

The compressive strength of concrete can also be analysed by means of the $w / b$,eff ratio (Table 6 ). It is obvious that the reduction of $\mathrm{w} / \mathrm{b}$, eff ratio leads to an increase in the compressive strength of concrete. The positive effect of fly ash by increasing packing density can be seen by comparing the concrete E2 with R23. The strength of concrete R23 is higher by approximately $10 \mathrm{MPa}$ although they both have the same $\mathrm{w} / \mathrm{b}_{\text {eff }}$ ratio.

However, despite a lower early-age strength of concrete containing some fly ash as cement replacement, many researches have shown that, due to its pozzolanic properties, fly ash actually increases the long-term strength of concrete.

\subsection{Capillary water absorption}

Changes in capillary water absorption (Uk) over time are shown in Figure 9, while coefficients of capillary water absorption for tested concretes are presented in Figure 10 (related to w/p ratio) and in Figure 11 (related to w/b,eff ratio).

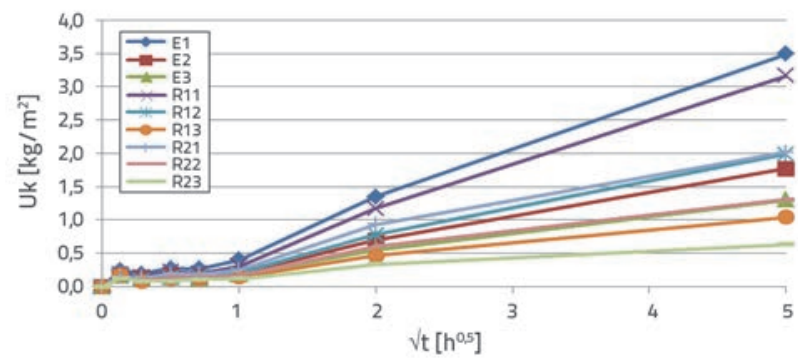

Figure 9. Correlation of capillary water absorption and square root of time

It was difficult to visually evaluate linear dependence of absorbed water at different time intervals. Consequently, a regression curve was pulled through and it was established that the correlation coefficient amounts to approximately 1, which proved linear behaviour of capillary water absorption.

During the first hour, all tested concretes showed slow water absorption. Between the period of $1 \mathrm{~h}$ and $4 \mathrm{~h}$ intensive absorption was noticed and, after that, the absorption decreased in the remaining test period.

It was observed that capillary absorption reduces with a decrease in the w/p or w/b,eff ratio, as shown in Figures 10 and 11. Also, the mixtures in which the cement was partially substituted with fly ash exhibited a lower capillary water uptake. In general, larger quantities of fly ash lead to lower water absorption (Figure 11). However, there was a deviation in the results obtained for $\mathrm{R} 12$ specimens, which is caused by unexplainable circumstances.

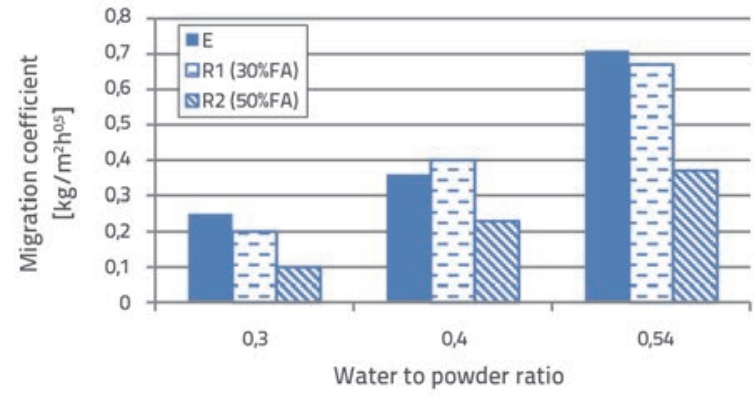

Figure 10. Correlation of capillary water absorption coefficient and $w / p$ ratio

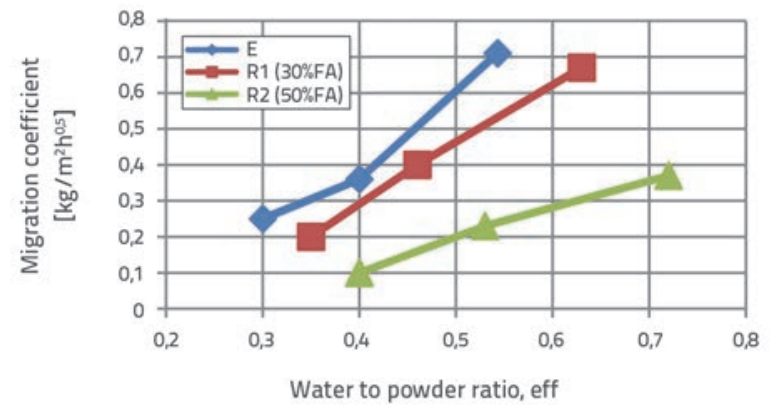

Figure 11. Correlation of capillary water absorption coefficient and w/ $b_{\text {eff }}$ ratio

\subsection{Chloride penetration}

All concrete mixtures exhibited high RCPT values. According to [13], the transport of ions in concrete depends on the pore structure of concrete, while the electrical conductivity of concrete or RCPT results depend on both the pore structure characteristics and the electrical conductivity of pore solution, which is determined by the composition of pore solution. Thus, it is not correct to use electrical conductivity of concrete or RCPT results to rank the chloride

Table 7. Non-steady state migration coefficient, $w / p$ ratio and effective $w / b$ ratio of RAC

\begin{tabular}{|c|c|c|c|c|c|c|c|c|c|}
\hline \multirow{2}{*}{ Concrete type } & \multicolumn{3}{|c|}{ RAC } & \multicolumn{3}{|c|}{ RAC (30\% FA) } & \multicolumn{3}{|c|}{ RAC (50 \% FA) } \\
\hline & E1 & E2 & E3 & R11 & R12 & R13 & R21 & R22 & R23 \\
\hline$w / p$ & 0.543 & 0.4 & 0.3 & 0.543 & 0.4 & 0.3 & 0.543 & 0.4 & 0.3 \\
\hline$w / b_{\text {eff }}$ & 0.543 & 0.4 & 0.3 & 0.63 & 0.46 & 0.35 & 0.72 & 0.53 & 0.4 \\
\hline $\mathbf{D}_{\mathrm{nssm}}\left[\times 10^{-12} \mathrm{~m}^{2} / \mathrm{s}\right]$ & 102.76 & 55.18 & 19.38 & 70.67 & 28.44 & 6.90 & 56.37 & 15.42 & 4.82 \\
\hline
\end{tabular}


permeability of concrete containing supplementary cementitious materials. In order to avoid misleading conclusions, colorimetric method was selected as an alternative test method.

The migration coefficients of concrete calculated according to the chloride penetration depths (Figure 5) are presented in Table 7. The results confirmed that the migration coefficient values lie within the range of $(4,82 \div 102.76) \times 10^{-12} \mathrm{~m}^{2} / \mathrm{s}$. According to the Nilsson's classification criteria, most concretes showed low resistance to chloride penetration $\left(>15 \times 10^{-12} \mathrm{~m}^{2} / \mathrm{s}\right.$ ). The exceptions are concretes with w/p $=0.3$ and with $30 \%$ and $50 \%$ of fly ash (R13 and R23), which exhibited good quality and high resistance to chloride penetration. Table 7 indicates that the resistance to chloride penetration increases with the addition of fly ash.

It can be concluded from the results given in Table 7 that the chloride ion penetration reduces if the fly ash content increases or/and the $w / p$ ratio decreases. However, the $w / p$ ratio was found to appreciably affect the chloride ion migration coefficient. Figure 12 shows the relationship between the non-steady-state migration coefficient and water to powder ratio for all tested concretes, which illustrates the aforementioned conclusions. According to estimation of concrete resistance to chloride ion penetration given in [12], the concretes with RCA (R13 and R23) could have a good resistance $\left(2-8 \times 10-{ }^{12} \mathrm{~m}^{2} / \mathrm{s}\right)$ only if FA is used in combination with low $w / b$,eff ratio (Figure 13 ). If the quantity of FA increases, the resistance to chloride ion penetration may be maintained at acceptable levels (8-16 x 10-12 $\left.\mathrm{m}^{2} / \mathrm{s}\right)$ even with higher $w / b_{\text {eff }}$ ratio (concrete $\mathrm{R} 22$ ).

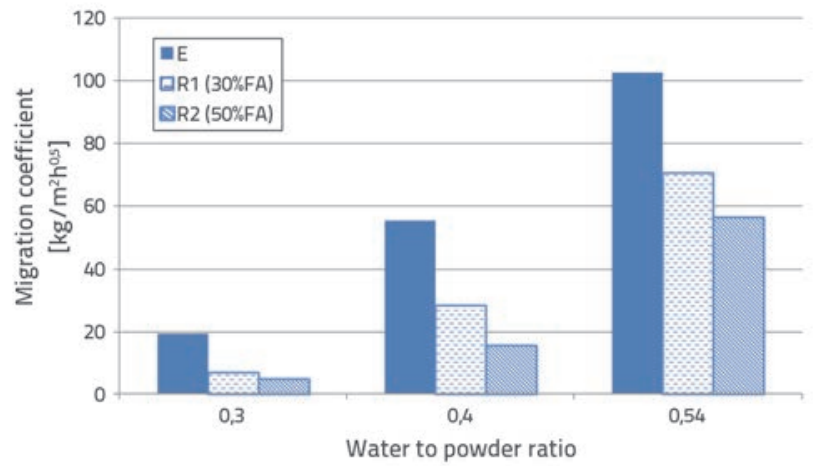

Figure 12. Correlation of non-steady-state migration coefficient and w/p ratio

The presented results refer to concrete samples at the age of 28 days. Therefore, it is expected that other samples, to be examined at a later time, will show greater resistance to chloride penetration [1].

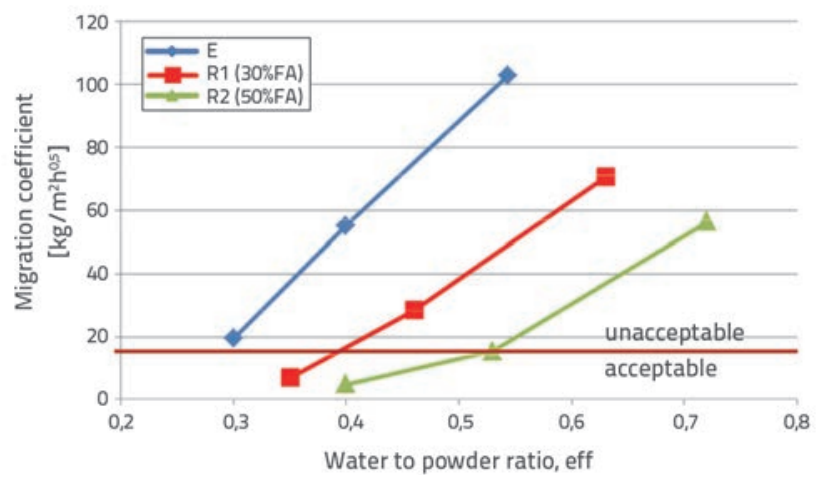

Figure 13. Correlation of non-steady-state migration coefficient and $w / b_{\text {eff }}$ ratio

\subsection{Depth of water penetration under pressure}

Test results are given in Table 8. Each presented value is the average of three measured values.

Concrete sample E1 has the highest value of water penetration depth, while concrete sample R23 has the lowest one.

The depth of water penetration for all tested concretes, as well as waterproofness criteria. are grabhicallv bresented in Figure 14.

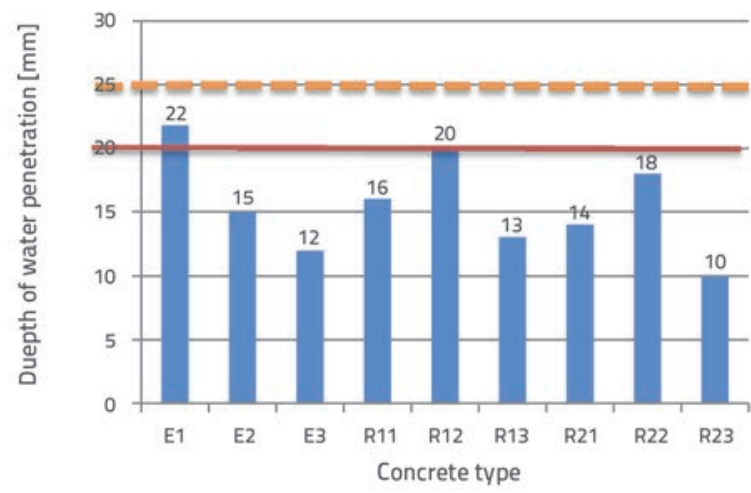

Figure 14. Depth of water penetration and waterproofness criterion

Based on the obtained water penetration depth values, it can be concluded that all concretes belong to the highest class of waterproofness, with the permitted water penetration value of $20+5 \mathrm{~mm}$ according to SRPS EN 206-1/1. The decrease in $\mathrm{w} / \mathrm{p}$ ratio led to the reduction in water permeability of $E$ concretes. In case of concretes containing fly ash, it can be seen that no specific correlation exists between the water to powder ratio and the water penetration depth. The effect of FA on water penetration depth could be clearly seen only in the group of

Table 8. Depth of water penetration

\begin{tabular}{|c|c|c|c|c|c|c|c|c|c|}
\hline \multirow{2}{*}{ Concrete type } & \multicolumn{3}{|c|}{ RAC } & \multicolumn{3}{|c|}{$\operatorname{RAC}(30 \% \mathrm{FA})$} & \multicolumn{3}{|c|}{ RAC (50\% FA) } \\
\hline & E1 & E2 & E3 & R11 & R12 & R13 & R21 & R22 & R23 \\
\hline$w / p$ & 0.543 & 0.4 & 0.3 & 0.543 & 0.4 & 0.3 & 0.543 & 0.4 & 0.3 \\
\hline$w / b_{\text {eff }}$ & 0.543 & 0.4 & 0.3 & 0.63 & 0.46 & 0.35 & 0.72 & 0.53 & 0.4 \\
\hline Depth [mm] & 22 & 15 & 12 & 16 & 20 & 13 & 14 & 18 & 10 \\
\hline
\end{tabular}


concretes with the largest porosity $\left(\mathrm{w} / \mathrm{p}=0.543\right.$ or $\mathrm{w} / \mathrm{b}_{\text {eff }} \geq$ 0.543). In that group, the waterproofness of concrete was improved by fly ash.

\section{Conclusion}

The idea behind this research was to produce concrete with an improved environmental, energy and $\mathrm{CO}_{2}$ impact. This was achieved by using recycled concrete aggregate and by partial cement replacement with fly ash. Besides having different amounts of cement replacement with fly ash, concrete mixtures also differed in the water-powder ratio, but all mixtures had the same type of macrostructure.

The compressive strength, capillary water absorption, chloride penetration, and depth of water penetration at the age of 28 days, were investigated. Based on the results obtained during this research, the following conclusions can be made:

- The compressive strength slightly decreases as the fly ash content increases. The concrete with $50 \%$ of fly ash and with $w / p=0,543$ has the compressive strength of $36 \mathrm{MPa}$, which is by $13 \%$ less than the compressive strength of the corresponding reference concrete. However, this reduction could be compensated by the use of a lower $w / p$ or $w / b, e f f$ ratio. For example, the compressive strength of concrete with $50 \%$ of fly ash and with $w / p=0,3$ is by $50 \%$ higher compared to that of the reference concrete with $\mathrm{w} / \mathrm{p}=$ 0,543 . Also, it is well known that the strength loss in the first month of hardening could change at a later period. Thus, fly ash brings subsequent increase in compressive strength as compared to the concrete without fly ash.

- The capillary water absorption decreases with a decrease in the $w / b$,eff ratio. Also, mixtures in which cement has been partially replaced with fly ash have a lower capillary water uptake.

- The resistance to chloride ion penetration significantly depends on the $w / b$,eff ratio and the fly ash content. The chloride ion penetration decreases with a decrease in the $\mathrm{w} / \mathrm{b}$, eff ratio and/or with an increase in the fly ash content. Concretes with $100 \%$ coarse RCA could exhibit acceptable and even good resistance to chloride ion penetration if high volume of fly ash is used in combination with a low water to

\section{binder ratio.}

- It is difficult to make a clear correlation between the fly ash content, w/p ratio, and water penetration depth, because all concretes exhibit small water penetration depth values (10-22 mm). However, it can be seen that reduction in $\mathrm{w} / \mathrm{c}$ ratio leads to improvement of waterproofness in concretes without fly ash. The positive effect of fly ash with regard to water penetration depth can be observed in concretes with the largest porosity $\left(w / p=0.543\right.$ or $\left.w / b_{\text {eff }} \geq 0.543\right)$.

This research is an attempt to create a sustainable concrete that produces environmental benefits during its production and use. The benefit of using any amount of recycled concrete aggregate would help limit the amount of industrial waste heading to landfills [14]. In this study, $100 \%$ of natural coarse aggregate was replaced with recycled concrete aggregate. This could lead to the reduction of construction waste and demolition waste, turning such waste into a natural resource for construction industry and limiting the size of our landfills. Also, 30\% and $50 \%$ of fly ash was used as cement replacement. As cement industry ranks among the largest sources of $\mathrm{CO}_{2}$ emissions, replacing just a portion of cement with fly ash can be regarded as a valuable contribution to the reduction of our carbon footprint.

The mixtures produced in this study, containing a large amount of fly ash, prepared with low w/p ratio and also with powerful super-plasticizers, provided high strength concretes with compressive strength values in excess of 60MPa. The use of mineral admixtures is promising in the light of their potential benefits for the durability and sustainability of reinforced concrete.

\section{Acknowledgements}

The work reported in this paper is a part of the investigation conducted within the research project TR 36017 "Utilization of by-products and recycled waste materials in concrete composites in the scope of sustainable construction development in Serbia: investigation and environmental assessment of possible applications", supported by the Ministry of Education, Science and Technological Development, Republic of Serbia. This support is gratefully acknowledged.

\section{REFERENCES}

[1] Silva, R.V., Brito, J., Neves, R., Dhir, R.: Prediction of Chloride Ion Penetration of Recycled Aggregate Concrete, Journal Materials Research, 18 (2015) 2, pp. 427-440.

[2] Hansen, T.C. Ed.: Recycling of Demolished Concrete and Masonry, Taylor and Francis, Oxfordshire, UK, pp. 316., 1992.

[3] Rahal, K.: Mechanical properties of concrete with recycled coarse aggregate. Building Environment, 1 (2007), pp. 407-415.

[4] Yang, K.H., Chung, H.S., Ashour, A.: Influence of type and replacement level of recycled aggregates on concrete properties, ACl Materials Journal, 3 (2008), pp. 289-296.
[5] Sanchez, J.M., Gutierrez, P.A.: Influence of recycled aggregate quality on concrete properties, Proceeding of the International RILEM Conference "The Use of Recycled Materials in Building and Structures", Barcelona, Spain, pp. 545-553, 2004.

[6] Berndt, M.L.: Properties of sustainable concrete containing fly ash, slag and recycled concrete aggregate, Construction and Building Materials, 23 (2009), pp. 2606-2613, https:// doi.org/10.1016/j. conbuildmat.2009.02.011 
[7] Vyas, C., Pitroda, J.: Fly Ash and Recycled Coarse Aggregate in Concrete: New Era for Construction Industries - A Literature Review, International Journal of Engineering Trends and Technology, 4 (2013) 5, pp. 1781-1787.

[8] Inthata, S., Kowtanapanich, W., Cheerarot, R.: Prediction of chloride permeability of concretes containing ground pozzolans by artificial neural networks, Materials and Structures, 46 (2013), pp. 1707-1721, https:// doi.org/10.1617/s11527-012-0009-x

[9] Obla, K.: Specifying Fly Ash for Use in Concrete, Concrete InFocus, pp. 60-66, 2008.

[10] Wu, P., Wang, X., Huang, T., Zhang, W.: Permeability and Prediction of Free Chloride Ion in Recycled Aggregate Concrete with Fly Ash, Int. J. Electrochem. Sci., 9 (2014), pp. 3513 - 3535.

[11] Naik, T., Singh, S., Hossain, M.: Permeability of high-strength concrete containing low cement factor, Journal of energy enginnering, 122 (1996), pp. 21-39.

[12] Zych, T.: Test methods of concrete resistance to chloride ingress, Technical Transactions - Civil Engineering, 6-B/2014, pp. 117139, 2014

[13] Shi, S.: Effect of mixing proportions of concrete on its electrical conductivity and the rapid chloride permeability test (ASTM C1202 or ASSHTO T277) results, Cement and Concrete Research, 34 (2004), pp. 537-545, https:// doi.org/10.1016/j. cemconres.2003.09.007

[14] Huda, S.B.: Mechanical and durability properties of recycled and repeated recycled coarse aggregate concrete, February 2014, pp. 1.

[15] Andrade, C., Prieto, M., Tanner, P., Tavares, F., d'Andrea, R.: Testing and modelling chloride penetration into concrete, Construction and Building Materials, 39 (2013), pp. 9-18, https:// doi. org/10.1016/j.conbuildmat.2012.08.012
[16] Shicong, K., Spoon, C.: Compressive Strength, Pore Size Distribution and Chloride-ion Penetration of Recycled Aggregate Concrete Incorporating Class-F Fly Ash, Journal of Wuhan University of Technology - Mater. Sci. Ed., 21 (2006) 4, pp. 300-306.

[17] Malešev, M., Radonjanin, V., Marinković, S.: Recycled Concrete as Aggregate for Structural Concrete Production, Sustainability, pp. 1204-1225, 2010.

[18] Radonjanin, V., Malešev, M., Marinković, S., Al Malty, A.E.S.: Green recycled aggregate concrete, Construction and Building Materials, 47 (2013), pp. 1503-1511, https:// doi.org/10.1016/j. conbuildmat.2013.06.076

[19] SRPS EN 196. Methods of testing cement

[20] SRPS U.M8.300. Determination of the capillary water absorption of building material and coatings

[21] BS 1881-122:2011 Testing concrete. Method for determination of water absorption.

[22] ASTM C 1202-2012. Standard Test Method for Electrical Indication of Concrete's Ability to Resist Chloride lon Penetration.

[23] NT BUILD 492. Concrete, mortar and cement-based repair materials: Chloride migration coefficient from non-steady-state migration experiments.

[24] SRPS EN 12390-8. Testing hardened concrete - Part 8: Depth of penetration of water under pressure.

[25] SRPS ISO 4012. Concrete - Determination of compressive strength of test specimens

[26] SRPS EN 206-1. Concrete: Specification, performance, production \& conformity

[27] EN 197-1. Cement - Part 1: Composition, specifications and conformity criteria for common cements 